\title{
Queer Practice as Research: a fabulously messy business
}

\section{Alyson Campbell and Stephen Farrier}

This short piece highlights a current spurt in queer researcher-practitioners doing Practice as Research $(\mathrm{PaR})$ in higher education ${ }^{1}$ and explores potential reasons why $\mathrm{PaR}$ is so vital, appealing, useful and strategic for queer research. As a starting point, we offer the idea of messiness and messing things up as a way of describing the methods of PaR. Queer mess is to do with asserting the value and pleasure of formations of knowledge that sit outside long-standing institutional hierarchies of research. The latter places, what Robin Nelson calls 'hard knowledge' above tacit, quotidian, haptic and embodied knowledge. ${ }^{2}$ The methodological and philosophical impulses of PaR make space for a range of research methods inherently bound up with the researcher as an individual and the materiality of lived experience within research. Yet, in our experience, while each $\mathrm{PaR}$ project is individual, $\mathrm{PaR}$ projects follow certain shared modes evolving largely from embodied and heuristic research methods adapted from social sciences, such as (auto)ethnography, participantobservation, phenomenology and action-research. ${ }^{3} \mathrm{PaR}$ methodology in theatre and performance is composed of a bricolage of these openly embodied methods, which makes PaR, as an embodied resistance to sanitary boundaries, somewhat queer in academic terms already. It is unsurprising, then, that $\mathrm{PaR}$ is so attractive to queer practitioner-researchers bent on queering normative hierarchies of knowledge.

\section{Erotics: desire and excess}

Because these methods are embodied, a large part of what attracts queers to $\mathrm{PaR}$ is its erotics, understood here in the Bataillean sense as both desire and excess, the 
expulsion of energy to no clear end, and as 'a form of expenditure which goes beyond use-value: it does not conserve energy but discharges it, consuming it in the act of using it and thereby destroying it. ${ }^{4}$ These unruly erotics in research are about sensations and the production of knowledge. Equally we would emphasise that such erotics are also about identity-formation in and around the research(er/s) through processes of self-reflection. As Elizabeth Freeman notes in her work on queer historiography, an erotic encounter with history (an erotohistoriography') 'sees the body as a method, and historical consciousness as something intimately involved with corporeal sensations. ${ }^{5}$ Within the context of queer performance and theatre studies this premise invites - often demands - a live encounter that produces an erotics between bodies through corporeal sensation: the body is the method. In queer PaR methodology it is the unruly and leaky body that presents the possibility of knowledge as somewhere beyond the apparent stability of theory's abstractions, and often beyond the notionally clean lines of academic disciplines. ${ }^{6}$ Queer PaR involves crossing disciplinary boundaries (often with scant regard to the propriety of those boundaries). These borders are both theoretical and disciplinary yet also literally physical, often testing the limits of inside and outside of bodies. ${ }^{7}$ Such probing produces quotidian or tacit knowledge that reflects what Robin Nelson calls 'liquid knowing', and in turn forms a relationship with 'hard' knowledge:

my model for PaR, whilst fully recognizing the importance of close-up, tacit, haptic know-how, seeks a means to establish as fully as possible an articulation of 'liquid knowing', and a shift through intersubjectivity into the know-what of shared and corroborated soft knowledge, in turn resonating with the harder know-that of established conceptual frameworks. ${ }^{8}$ 
Extending his image, we can think of queer $\mathrm{PaR}$ practitioners as bags of knowing liquid. Vitally, drawing on established feminist theorising, we can argue that liquid is hard to contain - it finds cracks and holes to permeate and flow through, thus coming into potentially eroding or corrosive contact with 'established conceptual frameworks'. ${ }^{9}$ This potential for change to established knowledges via corrosive or eroding contact - in other words for queer PaR to mess up/with these powerful and normalizing discourses - is what attracts queer researchers to the methodology.

\section{Messiness as methodology}

Leading (auto)ethnography scholars Stacey Holman Jones and Tony Adams argue that queer autoethnographic approaches can be seen as muddled, with 'too much personal mess' woven into the research, ${ }^{10}$ yet projects are structured by keeping processes messy, personal and liquid precisely to resist the normative impulse for cleanliness brought about by disciplining knowledge. Across projects that we lead or supervise, a number of methods arise in service of 'messiness'. These methods include a sensitivity to: the value of low-ranking quotidian forms of knowledge and embodiment (largely theorized through phenomenology and/or ethnography); the normalizing of temporalities; the politics and aesthetics of failure; a positioning that occupies or embodies the 'negative'; avowing desire and erotics in performance and an attraction to excess as a node in knowledge production and its (productive)

confusion. At the centre of these projects is a surprisingly simple point that cements the chain queerness-research-messiness: that is, queer in $\mathrm{PaR}$ is a lived experience that exceeds binary thinking, upsets unitary subjects and presents identities expressed in non-normative sexualities. Researchers take these identity positions to the heart of their research fields, studios and stages - and in so doing bring a fluid knowing, or 
messy existence, to the kinds of knowledges those research projects produce. Queer $\mathrm{PaR}$ is thus attracted to messiness as a methodology, where messiness is imbricated with queerness and where cleanliness in knowledge production is associated with knowledge forms that have routinely occluded the queer and the non-normative in an effort to tidy up hypotheses and conform to hegemonic forms of 'rigour'. Building on a growing set of literature that draws on ideas of mess, ${ }^{11}$ we assert that messiness requires its own (queer) rigour, as we demonstrate in the examples below.

\section{Messing up dramaturgies}

Campbell's research collaborator Ross Anderson's research into the phenomenology of the queer voice is activated through his performance in queer cabaret mode, or 'qabarett'. In his first qabarett performance integrating his research and practice (2011) he set out, as a 'bear' (a large, hairy, gay man) to be a sonic lesbian. His qabarett includes singing and much banter, or 'craic', with the audience. But this is queer as well as quare craic; this is apparent not just through the choice and content of songs - ranging from complex and clever reworkings of Disney classics, show-tunes and disco anthems to his favourite: diva power ballads - but through Anderson's specific use of vocal qualities. Anderson, an Estil (voice training method) master teacher, can only achieve his research through practice, setting his technical 'virtuosity' alongside his attempt, and his inevitable 'failure' (in any normatively understood sense), to be a lesbian. Thus, the methodological rigour here is in utilizing and simultaneously undermining the virtuosic voice. In doing so he questions assumptions about the normative voice and draws attention to the damage done to queers through the proliferation of normative and exclusionary academic and training 
methods that apply a 'rigour' that is debilitatingly silencing to the queer voice (both literal and metaphorical).

Likewise, 'failure' is inbuilt in the work of Farrier's former PhD student Nando Messias, who 'fails' to be a man because he 'cannot walk like one'. His doctoral practice, which neologized a 'sissiography', involved harnessing failure in the embodiment of the sissy as a positive identity position that, in turn, articulates through performance how heteronormative masculinities emerge in the body - and how one might resist these processes. ${ }^{12}$ His project engages failure as a mode of subjectivity related to the development and sustenance of the sissy and engages with failure as a queer PaR method. Taking the lead from a range of queer work on failure, the practice repeatedly enacted failure in performance through, for instance, falling, fighting and dancing in movement-based studio works, to works that involved Messias enacting sissyness on the streets of London. To be clear here, the chance of failure was real, rather than 'performed' and involved some personal physical risk. Through failure Messias discovered disseminable fundamental relations between the sissy body, abuse, and space.

Queer PaR projects such as these blur what might be a clear delineation between research and researcher. That in itself, in dominant research ideologies, is 'messy', inherently resisting the notion of 'objectivity' which - despite all the best efforts of poststructuralist contestation - still clings on to a key position in marking 'rigour'. The body, and its attendant erotics, are insurmountable, vividly present in these two exemplary works as autoethnographic mess: the bodies that 'fail', that 'mess up' in terms of attaining identity categories, and then revel in this failure. It is an old strategy - camp practices have done precisely this for a long time - but they are finding their own innovative performance practices to deal with the precise 
experience of embodiment that threatens the material safety of one body (Messias) and the phenomenological coherence of the other (Anderson).

Queer PaR happens then through this messy mode of practice, where the blurring of boundaries is productive. Queer PaR sits provocatively within the academy, resisting normative modes of knowledge production and valuation. Messiness here does not equate to methodlessness: by embracing failure, overflow, and unruly erotics these projects produce knowledge in ways that add to the field while raising questions about the functioning and ideological biases of the academy. They can only do this by finding their own 'rigour' - however queerly their work approaches that concept

\section{Endnotes}

${ }^{1}$ As encountered by the writers in their positions at Royal Central School of Speech and Drama, University of London (Farrier) and the Victorian College of the Arts, The University of Melbourne - and formerly at Queen's University Belfast (Campbell).

${ }^{2}$ Robin Nelson, Practice as Research in the Arts: Principles, Protocols, Pedagogies, Resistances (Basingstoke: Palgrave MacMillan, 2013), p. 60.

${ }^{3}$ See Nelson 2013; Estelle Barratt \& Barbara Bolt, eds, Practice as Research: Approaches to Creative Arts Enquiry (London: I.B. Tauris, 2007); John Freeman, Blood, Sweat and Theory: Research Through Practice in Performance (Faringdon: Libri Publishing,) 2010.

${ }^{4}$ Fred Botting \& Scott Wilson, eds, The Bataille Reader (Oxford: Blackwells, 1997), p.13.

${ }^{5}$ Elizabeth Freeman, Time Binds: Queer Temporalities, Queer Histories (Durham and London: Duke University Press, 2010) p. 96. 
${ }^{6}$ See Stephen Farrier, 'It's About Time: Queer Utopias and Theatre Performance', in Angela Jones, ed., A Critical Inquiry Into Queer Utopia (New York: Palgrave MacMillan, 2013).

${ }^{7}$ See http://www.josephmercier.com/take-it-like-a-man and http://www.daniploeger.org/\#!electrode/c3kk. Viewed 16 July 2014. ${ }^{8}$ Nelson, p. 60.

${ }^{9}$ For example, Anne Carson, 'Dirt and Desire: The Phenomenology of Female Pollution in Antiquity', in J.I. Porter, ed., Constructions of the Classical Body (Ann Arbor: University of Michigan Press, 2002) pp. 77 - 100.

${ }^{10}$ Stacey Holman Jones \& Tony E. Adams in Kath Browne and Catherine J. Nash, eds, Queer Methods and Methodologies Intersecting Queer Theories and Social Science Research (Surrey: Ashgate, 2010). p.197.

${ }^{11}$ For example, Tina Cook, 'The purpose of mess in action research: building rigour though a messy turn' Educational Action Research, 17, 2, 2009, pp. 277- 291; Deirdre Heddon and Jane Milling, Devising Performance: A Critical History (Basiingstoke: Palgrave Macmillan,2006) p. 192.

${ }^{12}$ Nando Messias, 'Towards a New Sissiography: The Sissy in Body, Abuse and Space in Performance Practice', unpublished PhD thesis, RCSSD, University of London, 2012. 